(C) The Author(s), 2020. Published by Cambridge University Press for the Arizona Board of Regents on behalf of the University of Arizona. This is an Open Access article, distributed under the terms of the Creative Commons Attribution licence (http://creativecommons.org/licenses/by/4.0/), which permits unrestricted re-use, distribution, and reproduction in any medium, provided the original work is properly cited.

\title{
RADIOCARBON DATING OF PRE-COLUMBIAN PERUVIAN FUNERARY BUNDLES OF THE CHANCAY CULTURE
}

\author{
Lukasz Majchrzak ${ }^{1 *}$ (D) Pieter van Dalen Luna ${ }^{2}$ - Tomasz Goslar ${ }^{3}$ \\ ${ }^{1}$ Jagiellonian University, Institute of Archeology, Kraków ul. Gołębia 11, 31-007 Kraków, Poland \\ ${ }^{2}$ Universidad Nacional Mayor de San Marcos, Escuela de Arqueologia, Germán Amézaga N 375-Edificio Jorge \\ Basadre, Ciudad Universitaria, Lima 1, Peru \\ ${ }^{3}$ Faculty of Physics, Adam Mickiewicz University, Umultowska 85, 61-614 Poznań, Poland, and Poznan Park of \\ Science and Technology, Foundation of the A. Mickiewicz University, Rubież 46, 61-612 Poznań, Poland
}

\begin{abstract}
The article presents the results of the absolute dating of 31 pre-Columbian funerary bundles excavated on the Cerro Colorado site located in the northern part of the Peruvian Central Coast, where the Chancay culture developed in the last centuries before the Spanish invasion. The typical custom in this region was to wrap the dead with textiles and a vegetal material, by which the bundle was created. The funerary bundles of the Cerro Colorado differed in terms of the complexity, quantity and quality of the materials used (especially textiles and metal ornament). Before our project, there was not a single radiocarbon $\left({ }^{14} \mathrm{C}\right)$ date for an undisturbed Chancay tomb, which made it impossible to understand the temporal dependency between the elaborated, standard, and modest bundles. Our results finally shed light on their proper chronological position, also demonstrating that the most elaborate bundles were created between the 13 th and 15 th centuries.
\end{abstract}

KEYWORDS: Chancay culture, funerary bundle, mummy, Peru, radiocarbon AMS dating.

\section{INTRODUCTION}

The pre-Columbian Chancay culture developed in the lower Chancay and Huaura valleys (the area locally known as the Norte Chico) between the 10th century and the second half of the 16th century. This period encompasses such archaeological epochs as the Middle Horizon (MH, 700-1050 AD), the Late Intermediate Period (LIP, 1050-1470) and the Late Horizon (LH, 1470-1533), when the territory was incorporated into the Inca empire or Tawantinsuyu. Despite the Spanish Conquest that began in AD 1533, the Chancay society continued until the year of 1560 , when the Colonial administration executed the process of reducciones, meaning the mandatory and violent resettlement of native communities to new, European-like cities. What they were leaving behind were extensive proto-urban settlements covered with impressive architectural constructions (including pyramid with ramp palatial complexes) and huge cemeteries. Shortly after, conquistadors and newcomers from Europe started the massive looting of burial and residential areas, a process that in fact continued until the present day. The outstanding pottery, textiles and metalwork stolen from the Chancay sites can be found today in many museums and private collections. All those materials lack archaeological context, precise provenience and chronology. Only a few archaeologists decided to study this culture (Horkheimer 1970; Fung 1972, 1995; Krzanowski 1991, 2008; Kaulicke 1997; Tello 2015). Pazdur and Krzanowski are unique for their publication of some radiocarbon $\left({ }^{14} \mathrm{C}\right)$ dates for the Chancay valley (Pazdur and Krzanowski 1991), and Brown et al. (2013) published some dates for the Huaura valley fortified settlements, including the one located close to the cemetery excavated by us.

In the period from 2014 to 2017, van Dalen and his team excavated a big part of the Cerro Colorado site located in the lower Huaura valley (Figure 1), one of the largest known preColumbian cemetery on the Peruvian Central Coast, today occupied by a modern

\footnotetext{
*Corresponding author. Email: archeoluk@gmail.com.
} 


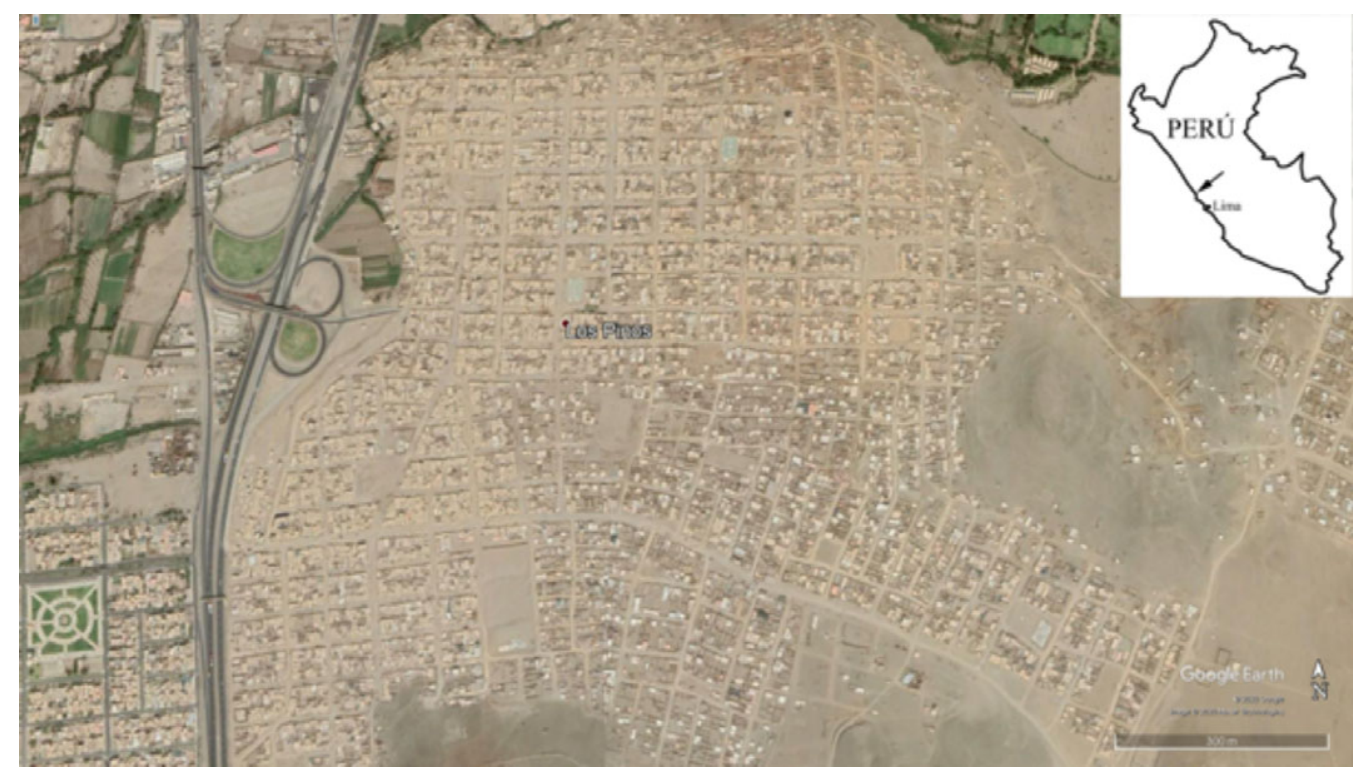

Figure 1 The part of the Cerro Colorado site excavated by van Dalen, covered by the modern Los Pinos settlement.

settlement Los Pinos $\left(11^{\circ} 07^{\prime} 02^{\prime \prime} \mathrm{S}, 77^{\circ} 35^{\prime} 23^{\prime \prime} \mathrm{W}\right)$. During the project, we discovered more than 1700 Chancay tombs, of which some $30 \%$ were still intact. The dominating funerary pattern on the Cerro Colorado was to wrap the dead with textiles and vegetal layers, creating the funerary bundle (Spanish: fardo funerario). Then the bundle was placed in a pit (the depth differed from 1.5 to $4 \mathrm{~m}$ ) together with such offerings as ware, tools, food, sometimes also the anthropomorphic figurines commonly known as the cuchimilcos. Stratigraphic study of more than 500 preserved bundles showed great variety between them in terms of the quantity and quality of textiles and artifacts placed inside. Some 30 bundles constituted a visibly distinct class, being extraordinarily complex, composed of high-quality mantles and sophisticated metal ornaments. Despite this, all the bodies (including those buried inside the extraordinary bundles) presented similar biological condition. The Cerro Colorado society performed physically demanding jobs, including weaving (women), fishing (men) and farming, for example. For some reason, and at some moment, some of the them gained access to high-quality materials, whereas the others did not.

The lack of the exact chronology (including the lack of the ceramic seriation) for this part of the Central Coast significantly impeded the interpretation of these discoveries. For that reason, we performed radiocarbon dating of different types of bundles, from those we considered modest to those that appeared elaborate.

\section{Funerary Bundles of Cerro Colorado}

The tradition of the bundle-type burials developed in the Paracas culture (ca. 800 BC to AD 100) on the Peruvian South Coast, and spread throughout the whole Central Andes during the Middle Horizon, with the cultural (perhaps also political) influence of the Wari state (Tello 2005; Giersz, Makowski 2016). When Spanish troops invaded the Inca empire, desiccated bodies of ancestors called "mallqui" (in Quechua "a young plant to put in soil" or "every 
fruitful tree", see Holquin 2007[1608]: 41) were revered by their descendants and relatives as divine beings. The ancestor cult included physical interaction with the dead, changing its clothes, cleaning the body and making offerings of food and corn beer or chicha. Thus, according to archaeologists, the objective of bundle-making was to transform the dead into powerful ancestors who had the capacity to create new life, like a dying seed which gives birth to a new plant (Makowski 2005; van Dalen 2017; van Dalen and Majchrzak 2019).

The funerary bundles of the Cerro Colorado were basically composed of mummified, semimummified or skeletonized human remains wrapped with textiles and vegetal layers. This was the dominant funerary pattern on the site, with less than $2 \%$ of individuals buried without the wrapping. Unfortunately, only around 500 bundles remained intact, as the site had been looted heavily in the past. Nevertheless, analysis of these bundles allowed the reconstruction of the funerary ritual step by step, including such processes as face painting, embalming, finger knotting and wrapping (van Dalen and Majchrzak in press; van Dalen et al. in press). What caught our attention was the great diversity among the bundles, especially concerning the quantity and quality of textiles personal ornaments.

\section{Textiles and Metal Ornaments Discovered in the Bundles}

In the last centuries before the Spanish invasion, textiles were the most desired and prestigious commodity in the Central Andes (Murra 1962). On the Cerro Colorado site, we identified more than 10 techniques of textile preparation and decoration, including such types as standard woven fabrics, tapestries, head-nets (redecillas) and gauzes, made of cotton and of camelid wool. Sometimes, as in case of tapestries, two materials were used at once, cotton for the warps and wool for the wefts. Whereas most textiles presented Chancay iconography, a tapestry from the $\mathrm{CF} \mathrm{Cl}^{1}$ bundle presented a style typical for the North Coast, where powerful Lambayeque and Chimu cultures developed, influencing cultural traditions of the Norte Chico (Figure 2).

Although there was a visible difference in the number of textiles (from two, as in the case of CF 23, to 20 in case of CF 30, or even 41 in the case of the Gran Fardo), the number did not always correspond to the quality. For example, a relatively "simple" bundle, CF 24, had only three textiles, but one of them was an excellent tapestry wrapped around the head, decorated with zoomorphic figures. The Gran Fardo bundle lacked tapestries, but, taking into account the number and quality of its textiles decorated with other techniques, there was no doubt that this one can be considered as the most complex on the whole site. Nevertheless, in most cases the bundles categorized as "elaborate" surpassed the "standard" ones not only in number, but also in the quality of the textiles used. Moreover, colonial documents show that bundle-making was a public event, where the relations between the dead and their relatives and subjects were materialized by the objects added to the bundle (van Dalen and Majchrzak 2019). Thus, the number and quality of the textiles (and other corporal ornaments) which wrap the body may hold information about the position a person maintained in society.

A common custom on the Cerro Colorado site, identified both in the "standard" and "elaborate" bundles, was to put one or two rectangular metal (usually copper) sheets on the face of the dead. This tradition was also noted in the Rimac valley, where the Ychma culture developed contemporary to the Chancay (Vetter 2011; Diaz 2015). In the case of CF 30, however, there were no fewer than seven sheets more than in any different case.

\footnotetext{
${ }^{1}$ The abbreviation CF (contexto funerario) refers to the feature number. The whole site was divided to Units (Unidad) and these were divided to sub-units (Subunidad), where each feature was given a burial number coded as CF.
} 

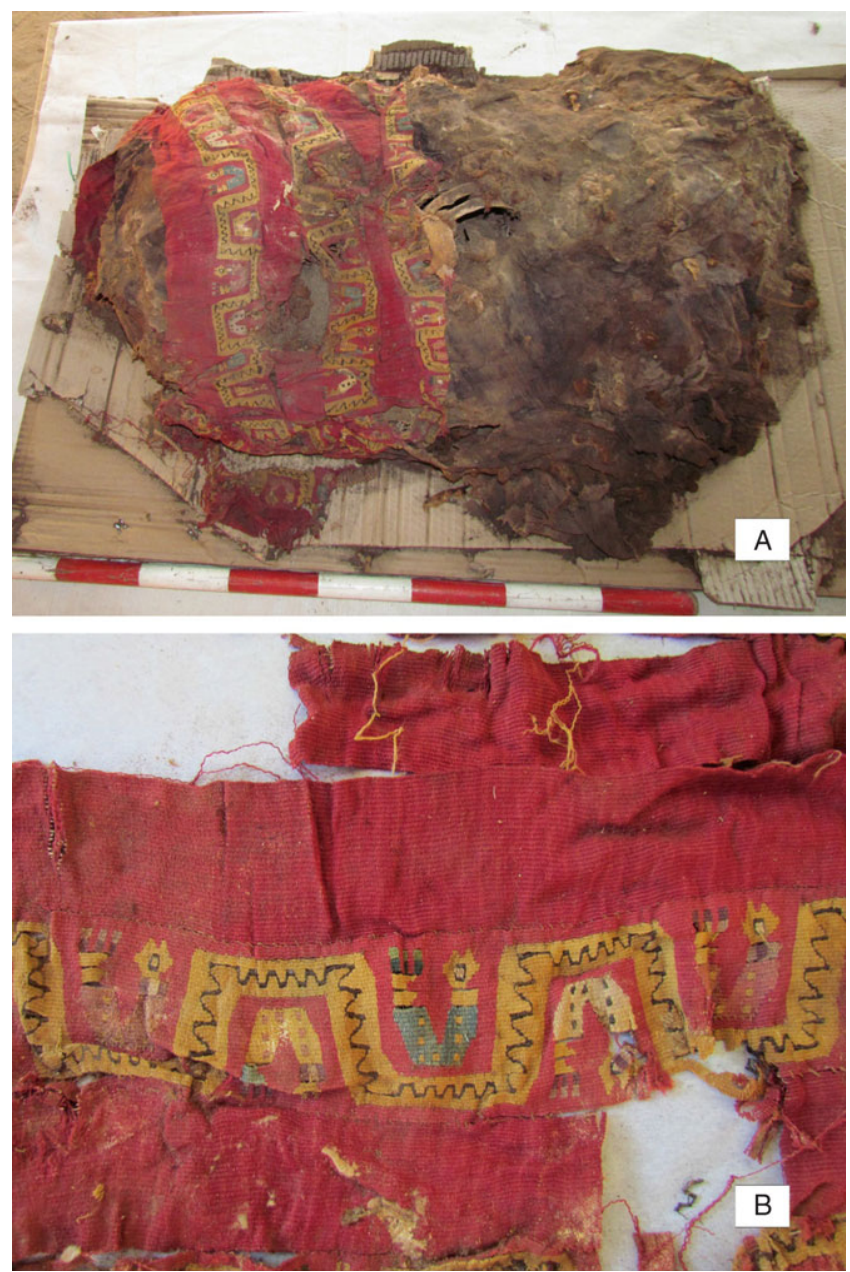

Figure 2 Funerary bundle of the CF C1 individual, with the tapestry possibly executed on the North Coast, placed in situ (A), and the detail of its decoration (B), a representation of a river (the zig-zag ornament) and fish (bent figures).

One was placed on the forehead, and there were a further four on each side of the face, separated by cotton layers (Figure 3). The CF 30 bundle is considered as an elaborate one also due to the presence of more than a 20 high quality textiles (Appendix: Table 2).

A much more outstanding type of artifact on the Cerro Colorado was a semilunar silver or copper sheet usually placed on the chest as a pectoral, or on the forehead as a head-dress. Among more than 1700 cadavers excavated by us, only 10 of them had such adornments, constituting a custom called by us "semilunar headdress tradition". Interestingly, documents written by various extirpators of idolatry mention that semi-lunar objects made of copper, gold or silver, named chacrahinca, were associated (among other elements of the attire) with the cult of huacas (sacred beings), and people also offered such objects to the mallqui, or sacred mummies (Arriaga 1968[1621]: 222). Moreover, these artifacts appear in 

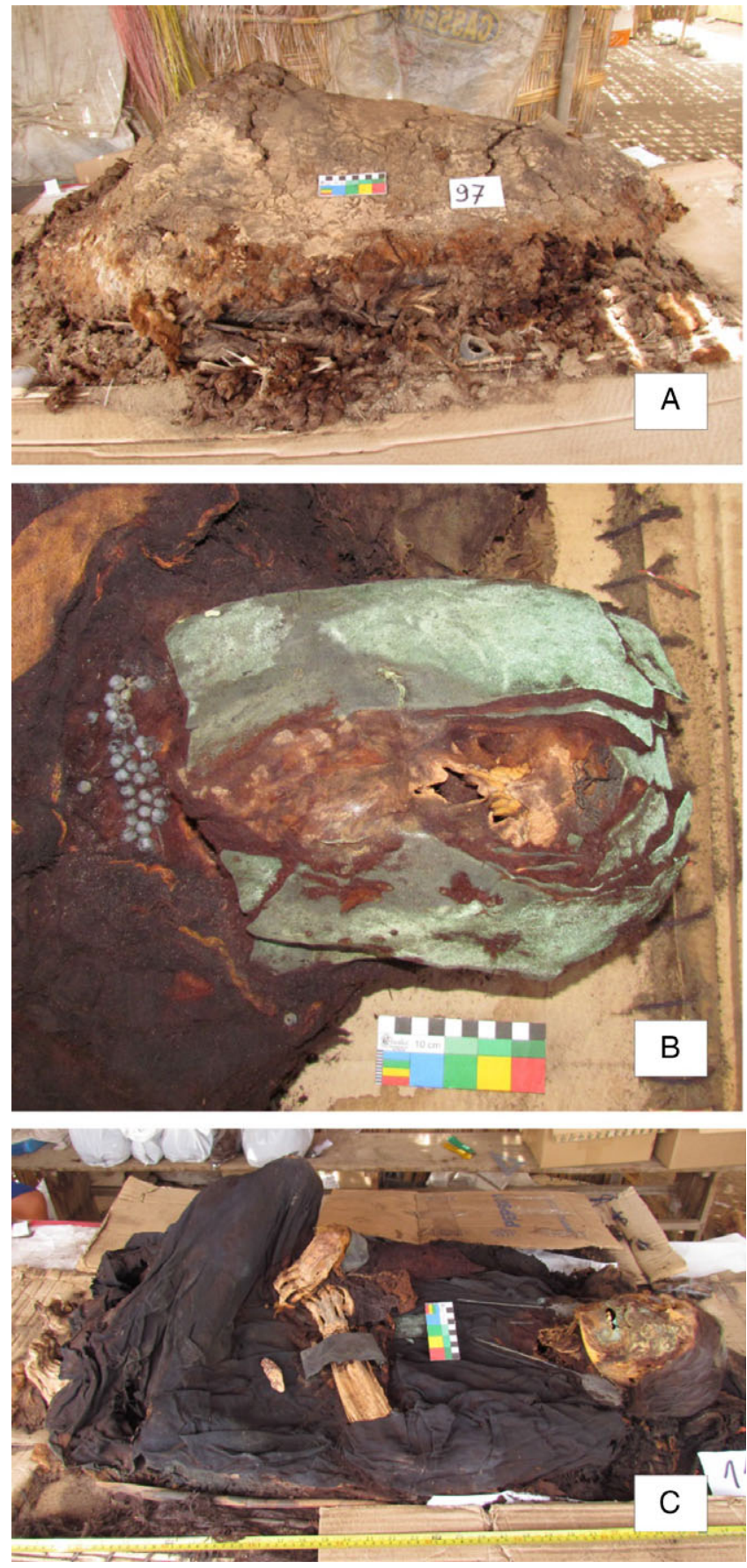

Figure 3 Funerary bundle CF 30: (A) the entire bundle, (B) the face sheets and the necklace, and (C) the mummified body (note the bracelets and tupu pins). 
Chimu and Lambayeque iconography, where divine-like individuals carry them on their foreheads; thus, according to Carcedo (2016), the semi-lunar head-dress was a symbol of the divinization of the ancestor. In our sample, the individual of the CF 41 bundle had two semilunar sheets. These were silver one placed on the chest as a pectoral, and a copper one on the forehead, with a row of white feathers on its upper edge, serving as a head-dress. The individual of the CF 43 bundle had two copper semi-lunar sheets placed on the head, one on the forehead and another on the occipital bone (Figure $4 \mathrm{~A}, \mathrm{~B}$ ). The individual of the CF 47 bundle had one silver semilunar sheet placed on his forehead. Interestingly, all three individuals, of the CF 41, CF 43, and CF 47 bundles, probably worked as fishermen, as indicated by bone tumors in their auditory canals. Moreover, their treatment differed from the rest, as their bodies were not entirely placed inside the bundles; instead, they were discovered in a flexed position on their back and covered with textiles, with the head as the unique part wrapped. The individual of the Gran Fardo also had his forehead covered with a semilunar copper sheet. However, its shape was different, being more like a semi-circle; and it was positioned differently, with the ends turned downwards, whereas in CF 43 and CF 47 the ends were turned upwards (Figure $4 \mathrm{C}$ ).

\section{Biological Condition of the Cerro Colorado People}

No matter whether buried in a "modest", "standard", or "elaborate" bundle, all remains of people who died older than 25 years had stress markers that clearly suggested the execution of physical work. This included degenerative joint disease and degenerative lesions of the spine, traditionally cited as an effect of physical work (Galtes et al. 2007). Among such conditions were osteophytosis, in many cases very advanced, including the ossification of the anterior ligament and the fusion of the vertebras, and Schmörl nodules. Even the man buried in the Gran Fardo had suffered these conditions in life, including extreme osteoarthritis of his joints, especially the elbows. This suggests that these people passed their life performing some physically demanding jobs such as fishing, farming, or weaving. Benign bone tumors (exostosis) in ear canals identified in some of the male skeletons and mummies normally grow due to the exposure to cold water and wind, conditions which are typical of the Pacific waters along the Andean coast (Silva-Pinto et al. 2013). Interestingly, except for the individual of the CF 31 bundle, all the men with semi-lunar head-dresses presented exostosis in both ears. It seems though, that the use of such adornment was reserved in this case for the men who worked on the sea.

\section{Objectives of the Study}

The lack of any existing absolute chronology or pottery seriation for the Huaura valley made it impossible to resolve various issues related to the layout of the bundles and the body treatment. The diversity between the quality and quantity of textiles and metal ornaments found in different bundles put in a question whether there was significant a chronological difference among them, what would suggest an evolution in their complexity. In turn, a lack of such difference would mean an existence of some kind of inequality inside the population.

\section{Selection of Bundles}

Stratigraphic analysis of the bundles showed that there was a clear division between the excavated area, with the less elaborate bundles encountered in the northern part (Units 11 and 42) and the most elaborate in the southern one (Units 10, 25, 27, 28, 30, and 40). Taking into account all these criteria, we selected 31 fardos excavated in both zones, on the basis of their layout and complexity, 

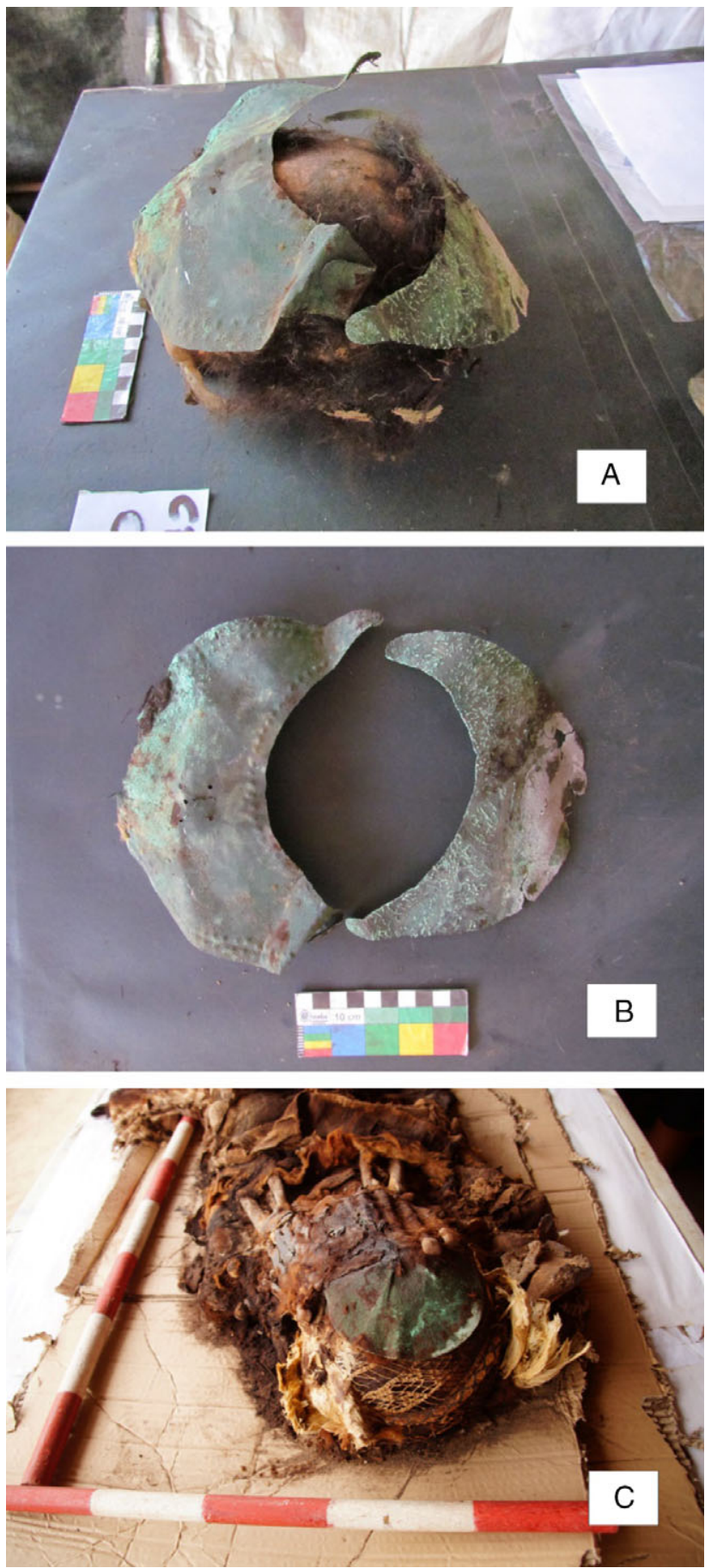

Figure 4 Semilunar head ornament or chacrahinca and two different ways of placing it: (A) copper sheets with ends directed upwards, in situ on the skull of the CF 43 individual, (B) the same sheets, and (C) a copper sheet with ends directed downwards, in situ on the forehead of the Gran Fardo individual. 
types of textiles and metals used, the occupation of the individuals, the state of the bodies (from fully mummified to skeletonized) and their treatment antemortem (especially tattoos, see: van Dalen et al. 2018). Moreover, we took into account the quantity of the diagnostic pottery associated with every bundle in a tomb, something that would allow us to create pottery seriation in the future. As the project "Biographies of the nameless" includes the isotopic analysis of hair with the aim of reconstructing diet, each bundle had to contain the individual with this still conserved. We divided bundles, on the basis on the complexity; the metal ornaments and the body treatment, into three groups (see also Table 2):

A. Elaborate bundles: CF 20, CF 41, CF12, CF 8, CF 112, CF 30, CF I, Gran Fardo, CF 31, CF 36, CF 43, CF C1, and CF 47.

B. Standard bundles: CF1 (Unit 28), CF 24, CF O-1, CF 53, CF 23, CF 46 (individual 2), CF W, CF 46 (individual 1), and CF 1 (Unit 30).

C. Modest bundles: CF 18, CF 38, CF 11, CF 7, 65, CF 72, CF 33, CF A-1, and CF 1 (Unit 11).

Group A includes bundles with the number of textiles greater than 11, or those with elaborate metal ornaments in the form of semi-lunar sheets (see below). Some of them also contained exotic materials, such as the cinnabar (in the Andes, a holy mineral), identified on the face of the women of the CF 112 and CF 12 bundles, or the feathers of Amazonian birds (the CF 112 bundle). Two bundles, the CF 30 and the Gran Fardo, constitute the "high end" of group A, in terms of the textiles and the metal ornaments used; also the individual of the CF 30 presented sophisticated tattoos which, together with the type of degenerative bone changes suggest she worked as a weaver. Group B includes bundles with the number of textiles between four and 11. The CF 24 and CF 1 (Unit 30) bundles had fewer textiles, but some of them were of high quality, and the CF 23 bundle had only two pieces, but also included metal ornamentation (see Table 2). Finally, Group $\mathrm{C}$ includes bundles with a number of textiles fewer than four, with no exceptional ones and without any significant metal ornaments, as well as those wrapped only in a cotton layer.

\section{MATERIALS AND METHODS}

\section{Sampling}

The samples were usually taken from the cotton layers that separated the textiles of the bundle, or the corn cobs put between them. In all cases we chose material placed within an undisturbed stratigraphic position, in order to eliminate the possibility of influence by external factors. In five cases (CF 38, 18, 11, 33, and CF 41), the vegetal material decomposed, so the sample was taken from the hair of the individuals. These samples are not considered in further discussion, due to lack of the ${ }^{15} \mathrm{~N}$ and ${ }^{13} \mathrm{C}$ measurements, and possible reservoir effect. In the case of the Gran Fardo the sample was taken from one of the textiles. One sample was taken for each burial, except for CF 46 of the Unit 27, where there were two bundles, and each one was sampled. Each sample was taken using disposable latex gloves and placed in a clean polyethylene bag.

\section{Pretreatment Procedure, Measurement, and Calibration}

${ }^{14} \mathrm{C}$ dating was performed at Poznań Radiocarbon Laboratory. Chemical pretreatment of the samples generally followed the protocols recommended by Brock et al. (2010). In particular, plant remains were treated with $1 \mathrm{M} \mathrm{HCl}\left(80^{\circ} \mathrm{C}, 20+\mathrm{min}\right), 0.025 \mathrm{NaOH}$ (room temperature, 
$1 \mathrm{hr})$, and then $0.25 \mathrm{M} \mathrm{HCl}\left(80^{\circ} \mathrm{C}, 1 \mathrm{hr}\right)$. For the first $\mathrm{HCl}$ treatment, a longer time $(20+)$ was applied if emanation of gas bubbles from the sample were still visible. The step of $\mathrm{NaOH}$ treatment was repeated a few times, until no more coloration of the $\mathrm{NaOH}$ solution appeared. For pre-treatment of human hair, a stronger $(0.1 \mathrm{M})$ solution of $\mathrm{NaOH}$ was applied. One sample of cotton textile (PRACC27) was additionally bleached with $2.5 \%$ $\mathrm{NaClO}_{2}$ (room temperature). After treatment with each reagent, the samples were rinsed with deionized water (Millipore) until $\mathrm{pH}=7$.

The samples were then combusted, and aliquots of the obtained $\mathrm{CO}_{2}$ were reduced (to solid carbon) with $\mathrm{H}_{2}$ using $2 \mathrm{mg}$ of $\mathrm{Fe}$ powder as a catalyst. Content of ${ }^{14} \mathrm{C}$ was measured with a compact carbon AMS spectrometer (Goslar et al. 2004). The measurements were performed by comparing intensities of ionic beams of ${ }^{14} \mathrm{C},{ }^{13} \mathrm{C}$ and ${ }^{12} \mathrm{C}$ measured for each sample and for standard samples (modern standard: Oxalic Acid II and standard of ${ }^{14}$ C-free carbon: "background"). Conventional ${ }^{14} \mathrm{C}$ ages were calculated using correction for isotopic fractionation (Stuiver and Polach 1977), based on the ratio ${ }^{13} \mathrm{C} /{ }^{12} \mathrm{C}$ measured in the AMS spectrometer simultaneously with the ratio ${ }^{14} \mathrm{C} /{ }^{12} \mathrm{C}$.

Calibration of ${ }^{14} \mathrm{C}$ age was performed with the OxCal program ver. 4.2 (Bronk Ramsey 2009; Bronk Ramsey and Lee 2013). In accordance with recent recommendations (Maresch et al. 2018) for the region from which we obtained our samples (the western coast of Peru), calibration was performed using the Southern Hemisphere calibration curve SHCal13 (Hogg et al. 2013).

\section{RESULTS AND DISCUSSION}

The results encompass the period from the end of the 9th to the middle of the 15th century (Appendix: Table 1). However, we have to exclude five dates (including first three in the Table 1), as these hair samples are lacking the ${ }^{13} \mathrm{C}$ and ${ }^{15} \mathrm{~N}$ measurements yet, so the verification of the reservoir effect is impossible.

Group A encompasses a period maximally between cal AD 1220 and 1459, group B is from 1203 to 1479 cal AD, and group C can be dated between AD 1215 and 1406 cal AD. The site was thus in use for at least two and a half centuries, probably abandoned with the incorporation of the Huaura valley into the Inca empire.

The results show that, in the 13th century, the Cerro Colorado society buried its dead in different ways, regardless of their biological condition. The two most elaborate bundles, CF

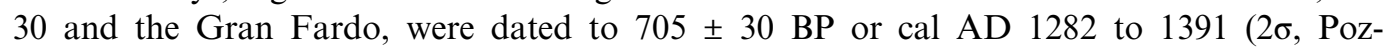

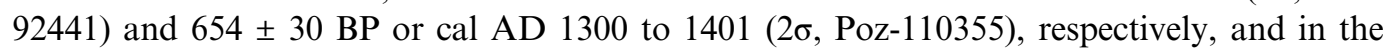
same period other individuals received more humble treatment, for example the man of $\mathrm{CF}$

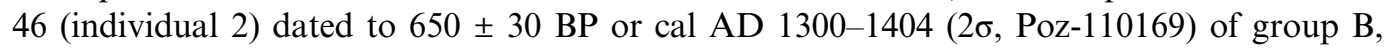

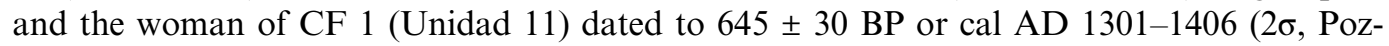
110167), of group C.

The results also give interesting information about the chronology of the "chacrahinca" or semilunar sheet tradition. Although the earliest date yielded for CF 41 cannot be taken as certain due to the possible reservoir effect (see above), two other results, $580 \pm 30 \mathrm{BP}$ or

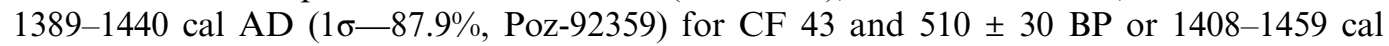
AD $(2 \sigma$, Poz-92419) for CF 47, place this tradition in the LIP, before the Inca arrival. This is important, as the only other place where such adornment was reported is the Altiplano 
region (Horta 2016). The transmission of the use such curious personal ornament from this distant region in the pre-Inca times seems rather impossible; thus, we are dealing probably with a distinct local religious tradition, performed only on few occasions.

The multidimensional interpretation of the presented results requires further studies, so we want to point out only a few observations here. The simultaneous execution of all three groups of bundles in the period between ca. 1270 and 1450 cal AD suggests the existence of some kind of inequality among the people who used the Cerro Colorado as their burial ground. However, the degree to which this was based on the political or social status of these individuals is a matter of discussion. Undoubtedly, all of them presented bone lesions resulting from the execution of heavy physical work, yet only a few were treated in an extraordinary way. Each of the A, B, and $\mathrm{C}$ groups includes both male and female individuals, so sex-based inequality is disputable. Also, they all used the same burial ground, and no spatial division was recorded. Unfortunately, we still have very scarce information on how political and social status was structured and expressed in the studied region in the Late Intermediate Period. The existence of differences in the complexity of funerary bundles was reported for different Central Coast LIP cemeteries in the Lurin and Rimac valleys (Michczyński et al. 2003; Eeckhout 2010; Vallejo 2008; Diaz 2015), as well as the Chancay valley (Pazdur and Krzanowski 1991; Kaulicke 1997; van Dalen 2017). Owens (2017) informs that people buried within the limits of the famous Pachacamac oracle in the Lurin valley presented degenerative bone changes similar to those recorded by us on the Cerro Colorado. While discussing funerary patterns in Pachacamac, Schimada et al. (2015:109) propose a multi-tier social division model based on access to different metals and cinnabar, developed for the northern Sican (Lambayeque) culture, with "high-silver-copper alloy" object possessed only by "high elite". The individuals of group A may represent such elite. Nevertheless, it is worth noting that all individuals had stress markers suggesting that during their life they performed physically demanding works. Thus they can be rather defined as "lower" than "higher" elite. They could be local leaders who still performed their working duties, perhaps the master craftsmen. The individuals of the $\mathrm{C}$ group would represent the lowest part of society, and the B group would gather all the people between these two extreme groups. However, taking into account the complexity of the spiritual and material world in the ancient Andes, such a scenario must be treated only as a working hypothesis which needs to be tested by future studies.

\section{CONCLUSION}

In the article, we present, for the first time, radiocarbon dates for the funerary bundles created by the poorly known pre-Columbian Peruvian Chancay culture and buried on the Cerro Colorado cemetery in the Huaura valley. These bundles present significant differences in their complexity, in terms of the quantity and the quality of materials used to wrap the dead (especially the metal ornament), and as our results inform, nearly all of them had been created in the last two centuries before the Inca arrival. All studied adult individuals presented degenerative bone changes which suggest the execution of heavy work, yet only some of them had access to luxurious copper and silver ornament, as well as embroidered textiles. This may suggest the existence of some kind of inequality between the people who performed same working activities, buried their dead on the same cemetery, and perhaps lived in the same place. We proposed a hypothesis, that the elaborated bundles (group A) might contain bodies of members of local elite. This assumption is weakened by two problems. Firstly, we still have little idea on how the social status was constructed and expressed in this period on the northern part of the Central Coast, where the Huaura valley 
is located. Secondly, the sample of 31 bundles can be little representative, taken into account the number of all funerary contexts excavated by van Dalen. For that reason, this article should be treated just as a point of departure in the discussion on the complexity and chronology of burial patterns among the late pre-Columbian Andean societies which dwelled Central Coast.

\section{ACKNOWLEDGMENTS}

The Cerro Colorado project was conducted under the auspices of the Universidad Nacional Mayor de San Marcos in Lima, through the projects of the Vice-rectorate of Research (131501115: " $\mathrm{La}$ Cultura Chancay en el Valle de Huaura"), co-financed by the District Municipality of Santa María. The radiocarbon dating was conducted as a part of the "Biographies of the nameless (... )", archaeometric project (the number of the grant: UMO 2015/19/N/HS3/00552 financed by the National Science Centre, address: ul. Twardowskiego 16, 30-312 Kraków, Poland. The authors want to thank to all archaeologists who took part in both projects, especially the site supervisor, Hans Grados Rodríguez, as well as to the Santa María major Dr. Juan Carlos García Romero and the authorities of the Los Pinos community, especially Constantino Rivera Valentín. We also thank to the Peruvian Ministry of Culture for the permission to take abroad the samples (Resolución Viceministerial Nro. 077-2017-VMPCIC-MC presented at 05 of May 2017). This study would never have been realized without the kind support of Dr. Andrzej Krzanowski, to whom we want to dedicate this article.

\section{REFERENCES}

Arriaga PJ. 1968 [1621]. Extirpación de la idolatría del Piru. Biblioteca de Autores Españoles, tomo 209 (Crónicas Peruanas de Interés Indígena). Madrid: Ediciones Atlas.

Brock F, Higham T, Ditchfield P, Bronk Ramsey C. 2010. Current pretreatment methods for AMS radiocarbon dating at the Oxford Radiocarbon Accelerator Unit (ORAU). Radiocarbon 52(1):103-112. doi: 10.1017/S0033822200045069.

Bronk Ramsey C. 2009. Dealing with outliers and offsets in radiocarbon dating. Radiocarbon 51(3):1023-1045. doi: 10.1017/S0033822200034093.

Bronk Ramsey C, Lee S. 2013. Recent and planned developments of the program OxCal. Radiocarbon 55(2-3):720-730. doi: 10.1017/ S0033822200057878.

Brown M, Craig NM, Culleton BJ, Kennet DJ, Lindo GA. 2013. AMS radiocarbon dates from Prehispanic fortifications in the Huaura Valley, Central Coast of Peru. Radiocarbon 55(1):1-12. doi: 10.2458/azu_js_rc.v55i1.16047.

Carcedo de Mufarech P. 2016. Personajes de élite en la orfebrería Sican: deidades, linajes y ancestros. In: Aimi A, Makowski K, Perassi Lambayeque E, editors. Nuevos horizontes de la arqueología peruana. Milano: Ledizioni. p. 183-2016. doi: digital.casalini.it/3447014.

Diaz Arriola L. 2015. The preparation of corpses and mummy bundles in Ychsma funerary practices at Armatambo. In: Eeckhout P, Owens L, editors. Funerary practices and models in the ancient Andes. Cambridge University Press. p. 186-209. doi: 10.1017/CBO9781107444928.012.
Eeckhout P. 2010. Nuevas evidencias sobre costumbres funerarias en Pachacamac. In: Kaulicke P, Fischer M, Masson P, Wolff G, editors. Max Uhle (1856-1944). Evaluaciones de sus investigaciones y obras. Fondo Editorial de la Pontificia Universidad Católica del Perú, Lima. p. 151-163.

Fung R. 1972. El arte textil en el antiguo Perú: sus implicancias económicas, sociales, políticas $\mathrm{y}$ religiosas. Proceso 1:20-23. Universidad Nacional del Centro del Perú. Huancayo.

Fung R. 1995. Los encajes hechizados de la cultura Chancay. Boletín de la Fundación Museo Amano 7:1-13. Lima.

Galtes I, Jordana X, García C, Malgosa A. 2007. Marcadores de actividad en restos óseos. Cuad med. forense 13(48-49):179-189. doi: 10.4321/ S1135-76062007000200006.

Giersz M, Makowski K. 2016. El imperio en debate: hacia nuevas perspectivas en la organización política Wari. In: Giersz M, Makowski K, editors. Nuevas perspectivas en la organización política Wari. Andes. Boletín del Centro de Estudios Precolombinos de la Universidad de Varsovia 9:5-39. Varsovia-Lima.

Goslar T, Czernik J, Goslar E. 2004. Low-energy ${ }^{14} \mathrm{C}$ AMS in Poznan Radiocarbon Laboratory, Poland. Nuclear Instruments and Methods in Physics Research B 223-224:5-11. doi: https://doi. org/10.1016/j.nimb.2004.04.005.

Hogg AG, Hua Q, Blackwell PG, Niu M, Buck CE, Guilderson TP, Heaton TJ, Palmer JG, Reimer PJ, Reimer RW. 2013. SHCal13 Southern 
Hemisphere calibration, 0-50,000 cal yr BP. Radiocarbon 55(2):1889-1903. doi: https://doi. org/10.2458/azu_js_rc.55.16783.

Horta Tricallotis H. 2016. The chin adornment of the highland lords as a symbol of historical continuity and ethnic emblem in the Southern Andes (6001600 AD). Chungara 48(3):365-382. http://dx. doi.org/10.4067/S0717-73562016005000025.

Horkheimer H. 1970. Chancay prehispánico: diversidad y belleza. In: Ravines R, editor. 100 años de arqueología en el Perú. Lima: Petroperú. p. 363-378.

Kaulicke P. 1997. Contextos funerarios en Ancón. Pontificia Universidad Católica del Perú. Lima.

Krzanowski A, editor. 1991. Estudios sobre la Cultura Chancay. Kraków: Universidad Jaguellona.

Krzanowski A. 2008. Kultura Chancay. Środkowe wybrzeże Peru. Polskie Towarzystwo Studiów Latynoamerykanistycznych, Instytut Amerykan istyki i Studiów Polonijnych UJ. 228 p.

Makowski K. 2005. Deificación frente a ancestralización del gobernante en el Perú prehispánico: Sipán y Paracas. In: Arqueología, geografía e historia. Aportes peruanos en el 50 congreso de Americanistas. Varsovia, Polonia 2000. Lima PUCP, Fondo Editorial-PromPerú, Lima. p. 39-80.

Marsch EJ, Bruno MC, Fritzs SC, Baker P, Capriles JM, Hastorf CA. 2018. IntCal, SHCal, or a mixed curve? Choosing a ${ }^{14} \mathrm{C}$ calibration curve for archaeological and paleoenvironmental records from tropical South America. Radiocarbon 60(3):925-940. doi:https://doi.org/10.1017/RDC. 2018.16.

Michczyński A, Eeckhout P, Pazdur A. $2003 .{ }^{14} \mathrm{C}$ absolute chronology of Pyramid III and the dynastic model at Pachacamac, Peru. Radiocarbon 45(1):59-73.

Murra J. 1962. Cloth and its function in the Inca state. American Anthropologist 64(4):710-728. DOI https://doi.org/10.1525/aa.1962.64.4.02a00020.

Owens L. 2017. Los restos humanos de Pachacamac. In Pachacamac: el Oraculo en el Horizonte Marino del Sol Poniente, p. 238-251. Volume 44 in the BCP "Arte y Tesoros del Perú" series.

Pazdur MF, Krzanowski A. 1991. Fechados radiocarbonicos para los sitios de la cultura Chancay. In: Krzanowski A, editor. Estudios sobre la Cultura Chancay. p. 115-132.
Shimada I, Segura Llanos R, Matsumoto G. 2015. Living with the dead: conception and treatment of the dead on the Peruvian coast. In: Shimada I, Fitzimmons J, editors. Living with the dead in the Andes. Tucson: University of Arizona Press. p. 101-170.

Silva-Pinto V, Valenzuela D, Sepúlveda M. 2013. Paleopatología osteoarticular en Chinchorro. Revisión de un caso y discusión sobre el autocuidado en la prehistoria de Arica, norte de Chile. Rev. méd. Chile 5(141):637-643. doi: 10. 4067/S0034-98872013000500012.

Stuiver M, Polach HA. 1977. Discussion: reporting of ${ }^{14} \mathrm{C}$ data. Radiocarbon 19(3):355-363. doi: 10. 1017/S0033822200003672.

Tello JC. 2005. Paracas, primera parte. Lima: UNMSM: Fondo editorial, New York: Institute of Andean Studies.

Tello JC. 2015. Arqueología del territorio Chancay. In: Cuadernos de Investigación del Archivo Tello 11. Lima: Museo de Arqueología y Antropología de la Universidad Nacional Mayor de San Marcos.

Vallejo F. 2008. Desarrollo y complejización de las sociedades tardías de la Costa Central: el caso de Ychsma. Arqueología y Sociedad 19: 83-114.

Vetter L. 2011. El status quo de la tecnología metalúrgica en la costa central y norte del Perú durante del Periodo Intermedio Tardío. Arqueología y Sociedad 23:133-157.

Van Dalen P. 2017. Sacachispa: un cementerio de agricultores de la cultura Chancay en Huando, Huaral. Lima. 212 p.

Van Dalen P, Majchrzak L. 2019. Estratigrafía y componentes de un fardo funerario de la cultura Chancay procedente de Cerro Colorado, Huacho. Investigaciones Sociales 22(41):79-91. doi: 10.15381/is.v22i41.16767.

Van Dalen P, Majchrzak L, Malek K, Kuncewicz K, Miśkowiec P. In press. The multimodal chemical study of the pre-Columbian Peruvian mummies.

Van Dalen P, Altamirano A, Majchrzak L. 2018. Marcas para la vida, señales para la muerte. Los cuerpos tatuados de la cultura Chancay en Cerro Colorado, Huacho, Perú. Revista M. Estudos sobre a morte, os mortos o morrer 3(6):344-377. doi: 10.9789/2525-3050.2018.v3i6. p. $\% 20344-377$. 


\section{APPENDIX}

Table 1 Results of AMS radiocarbon dating of funerary bundles presented in the article. *Samples excluded from further analysis in the article, due to the lack of the ${ }^{15} \mathrm{~N}$ and ${ }^{13} \mathrm{C}$ measurements, and a possible reservoir effect.

\begin{tabular}{|c|c|c|c|c|c|c|c|}
\hline Sample ID & $\begin{array}{l}\text { Location of the burial } \\
\text { on the site }\end{array}$ & Lab code & Sample type & $\begin{array}{c}\delta^{13} \mathrm{C}_{\mathrm{AMS}} \\
(\% 0)\end{array}$ & $\begin{array}{l}{ }^{14} \mathrm{C} \text { age } \\
\text { (BP) }\end{array}$ & $1 \sigma$ calibrated age & $2 \sigma$ calibrated age \\
\hline PRACC $34^{*}$ & $\begin{array}{l}\text { Unidad 42, Subunidad } \\
\text { 6, CF } 38\end{array}$ & Poz-110196 & Human hair & -11.2 & $1115 \pm 30$ & $\begin{array}{c}906-919(10.2 \%) \\
969-1018(58.0 \%)\end{array}$ & $\begin{array}{r}893-940\left(26.5^{\circ}\right) \\
950-1025\left(68.9^{\circ} \%\right)\end{array}$ \\
\hline PRACC 33* & $\begin{array}{l}\text { Unidad 42, Subunidad } \\
\quad 6, \mathrm{CF} 18\end{array}$ & Poz-110195 & Human hair & -7.3 & $1085 \pm 30$ & $989-1023(68.2 \%)$ & $\begin{array}{r}896-931(6.2 \%) \\
961-1044(89.0 \%) \\
1124-1127(0.2 \%)\end{array}$ \\
\hline PRACC18* & $\begin{array}{l}\text { Unidad 10, Subunidad } \\
12, \mathrm{CF} 11\end{array}$ & Poz-110350 & Human hair & -15.6 & $960 \pm 30$ & $\begin{array}{c}1046-1088(33.4 \%) \\
1110-1116(3.0 \%) \\
1130-1177(31.8 \%)\end{array}$ & $1032-1192(95.4 \%)$ \\
\hline PRACC31 & $\begin{array}{l}\text { Unidad } 42 \text {, Subunidad } \\
\text { 6, CF } 65\end{array}$ & Poz-109988 & $\begin{array}{l}\text { Plant remains } \\
\text { (calabash) }\end{array}$ & -26.2 & $825 \pm 30$ & $1229-1270(68.2 \%)$ & $1209-1284(95.4 \%)$ \\
\hline PRACC11 & $\begin{array}{l}\text { Unidad 28, Subunidad } \\
\qquad 1, \mathrm{CF} 1\end{array}$ & Poz-92437 & Cotton & -20.1 & $830 \pm 30$ & $1225-1268(68.2 \%)$ & $1203-1284(95.4 \%)$ \\
\hline PRACC35 & $\begin{array}{l}\text { Unidad } 42 \text {, Subunidad } \\
\text { 7, CF } 72\end{array}$ & Poz-109989 & Cane & -21.1 & $815 \pm 30$ & $1230-1275(68.2 \%)$ & $1215-1286(95.4 \%)$ \\
\hline PRACC25 & Unidad 2, CF 20 & Poz-110171 & Cotton & -17.0 & $800 \pm 30$ & $\begin{array}{l}1230-1251(30.4 \%) \\
1261-1282(37.8 \%)\end{array}$ & $1220-1290(95.4 \%)$ \\
\hline PRACC19* & $\begin{array}{l}\text { Unidad 10, Subunidad } \\
12, \mathrm{CF} 41\end{array}$ & Poz-110352 & Human hair & -13.8 & $785 \pm 30$ & $\begin{array}{l}1232-1248(18.2 \%) \\
1262-1290(50.0 \%)\end{array}$ & $1220-1300(95.4 \%)$ \\
\hline PRACC10 & Unidad 40, CF12 & Poz-92436 & Corn & -9.0 & $780 \pm 30$ & $\begin{array}{c}1234-1245(12.5 \%) \\
1264-1292(55.7 \%) \\
1365-1375(2.3 \%)\end{array}$ & $1221-1303(93.1 \%)$ \\
\hline PRACC15 & $\begin{array}{l}\text { Unidad 10, Subunidad } \\
12, \mathrm{CF} 7\end{array}$ & Poz-92442 & Corn & -4.6 & $760 \pm 30$ & $\begin{array}{c}1268-1302(62.8 \%) \\
1366-1373(5.4 \%)\end{array}$ & $\begin{array}{l}1229-1315(81.2 \%) \\
1356-1382(14.2 \%)\end{array}$ \\
\hline
\end{tabular}

(Continued) 


\begin{tabular}{|c|c|c|c|c|c|c|c|}
\hline Sample ID & $\begin{array}{l}\text { Location of the burial } \\
\text { on the site }\end{array}$ & Lab code & Sample type & $\begin{array}{c}\delta^{13} \mathrm{C}_{\mathrm{AMS}} \\
(\% 0)\end{array}$ & $\begin{array}{l}{ }^{14} \mathrm{C} \text { age } \\
\text { (BP) }\end{array}$ & $1 \sigma$ calibrated age & $2 \sigma$ calibrated age \\
\hline PRACC36 & $\begin{array}{l}\text { Unidad 42, Subunidad } \\
\text { 4. CF } 24\end{array}$ & Poz-110197 & Cotton & -22.6 & $735 \pm 30$ & $\begin{array}{l}1280-1307(45.1 \%) \\
1361-1378(23.1 \%)\end{array}$ & $\begin{array}{l}1271-1322(60.3 \%) \\
1349-1387(351 \%)\end{array}$ \\
\hline PRACC7 & $\begin{array}{l}\text { Unidad 27, Subunidad } \\
\text { 2, CF } 8\end{array}$ & Poz-92433 & Cotton & -18.9 & $725 \pm 30$ & $\begin{array}{l}1285-1310(40.6 \%) \\
1360-1379(27.6 \%)\end{array}$ & $\begin{array}{l}1274-1324(54.1 \%) \\
1346-1389(41.3 \%)\end{array}$ \\
\hline PRACC12 & $\begin{array}{l}\text { Unidad 25, Subunidad } \\
\text { 2, CF } 112\end{array}$ & Poz-92439 & Cotton & -21.6 & $710 \pm 30$ & $\begin{array}{l}1291-1316(33.8 \%) \\
1356-1381(34.4 \%)\end{array}$ & $\begin{array}{l}1280-1327(46.7 \%) \\
1340-1391(48.7 \%)\end{array}$ \\
\hline PRACC21 & $\begin{array}{l}\text { Unidad 27, Subunidad } \\
\text { 1, CF } 53\end{array}$ & Poz-110168 & Corn & -5.2 & $700 \pm 30$ & $\begin{array}{l}1294-1318(30.9 \%) \\
1354-1383(37.3 \%)\end{array}$ & $\begin{array}{l}1285-1328(43.6 \%) \\
1338-1391(51.8 \%)\end{array}$ \\
\hline PRACC14 & $\begin{array}{l}\text { Unidad 10, Subunidad } \\
12, \text { CF } 30\end{array}$ & Poz-92441 & Corn & -6.4 & $705 \pm 30$ & $\begin{array}{l}1293-1317(31.7 \%) \\
1355-1382(36.5 \%)\end{array}$ & $\begin{array}{l}1282-1328(44.6 \%) \\
1340-1391(50.8 \%)\end{array}$ \\
\hline PRACC32 & Gran Fardo & Poz-110355 & Cotton textile & -27.7 & $654 \pm 30$ & $\begin{array}{l}1315-1357(52.6 \%) \\
1382-1395(15.6 \%)\end{array}$ & $1300-1401(95.4 \%)$ \\
\hline PRACC23 & $\begin{array}{l}\text { Unidad 27, Subunidad } \\
\text { 1, CF } 46 \\
\text { (Individual 2) }\end{array}$ & Poz-110169 & Cotton & -17.1 & $650 \pm 30$ & $\begin{array}{l}1315-1355(50.4 \%) \\
1382-1397(17.8 \%)\end{array}$ & $1300-1404(95.4 \%)$ \\
\hline PRACC20 & Unidad $11, \mathrm{CF} 1$ & Poz-110167 & Cotton & -18.5 & $645 \pm 30$ & $\begin{array}{l}1318-1354(50.1 \%) \\
1383-1398(18.1 \%)\end{array}$ & $1301-1406(95.4 \%)$ \\
\hline
\end{tabular}


Table 1 (Continued)

\begin{tabular}{|c|c|c|c|c|c|c|c|}
\hline Sample ID & $\begin{array}{c}\text { Location of the burial } \\
\text { on the site }\end{array}$ & Lab code & Sample type & $\begin{array}{c}\delta^{13} \mathrm{C}_{\mathrm{AMS}} \\
(\% 0)\end{array}$ & $\begin{array}{l}{ }^{14} \mathrm{C} \text { age } \\
\text { (BP) }\end{array}$ & $1 \sigma$ calibrated age & $2 \sigma$ calibrated age \\
\hline PRACC28 & Unidad 10, Subunidad & Poz-110354 & Corn & -9.9 & $640 \pm 30$ & $1319-1352(48.8 \%)$ & $1302-1367(64.6 \%)$ \\
\hline & 12 , CF 36 & & & & & 1385-1399 (19.4\%) & $\begin{array}{l}1373-1409(30.8 \%) \\
1301-1367(648 \%)\end{array}$ \\
\hline PRACC27 & $\begin{array}{l}\text { Unidad 10, Subunidad } \\
12, \mathrm{CF} 31\end{array}$ & Poz-110356 & Cotton textile & -24.0 & $640 \pm 30$ & $\begin{array}{l}1319-1352(49.3 \%) \\
1385-1399(18.9 \%)\end{array}$ & $\begin{array}{l}1301-1367(64.8 \%) \\
1373-1410(30.6 \%)\end{array}$ \\
\hline PRACC3 & $\begin{array}{l}\text { Unidad } 28 \text {, Subunidad } \\
1, \mathrm{CF} \text { W }\end{array}$ & Poz-92358 & Corn & -6.2 & $590 \pm 30$ & $1392-1426(68.2 \%)$ & $\begin{array}{l}1320-1350(16.8 \%) \\
1386-1438(78.6 \%)\end{array}$ \\
\hline PRACC4 & $\begin{array}{l}\text { Unidad 10, Subunidad } \\
12, \mathrm{CF} 43\end{array}$ & Poz-92359 & Cane & -22.4 & $580 \pm 30$ & $1396-1427(68.2 \%)$ & $\begin{array}{r}1325-1343(7.5 \%) \\
1389-1440(87.9 \%)\end{array}$ \\
\hline PRACC6 & $\begin{array}{l}\text { Unidad 28, Subunidad } \\
\text { 1, CF C-1 }\end{array}$ & Poz-92420 & Cotton & -28.6 & $580 \pm 30$ & $1396-1427(68.2 \%)$ & $\begin{array}{r}1324-1343(7.8 \%) \\
1389-1440(87.6 \%)\end{array}$ \\
\hline PRACC 30 & $\begin{array}{l}\text { Unidad 27, Subunidad } \\
\text { 1, CF } 46 \\
\text { (Individual 1) }\end{array}$ & Poz-118194 & $\begin{array}{l}\text { Plant remains } \\
\text { (unidentified) }\end{array}$ & -26.7 & $565 \pm 30$ & $1402-1430(68.2 \%)$ & 1391-1447 (95.4\%) \\
\hline PRACC5 & $\begin{array}{l}\text { Unidad 10, Subunidad } \\
12, \text { CF } 47\end{array}$ & Poz-92419 & Cane & -27.2 & $510 \pm 30$ & $1424-1450(68.2 \%)$ & $1408-1459(95.4 \%)$ \\
\hline PRACC29 & $\begin{array}{l}\text { Unidad } 30 \text {, Subunidad } \\
5, \mathrm{CF} 1\end{array}$ & Poz-110172 & Corn & -5.2 & $495 \pm 30$ & $1429-1455(68.2 \%)$ & $1411-1479(95.4 \%)$ \\
\hline
\end{tabular}


Table 2 The main characteristics of funerary bundles presented in the article. Gender refers to the sex of the individual buried in the bundle; $\mathrm{M}$-male, and $\mathrm{F}$ - female. Age — estimated age at death of the individual. Group — refers to the division on the basis described in the main article. Number of textiles - the total amount of textiles in the bundle. Silver ornament-total amount of silver objects in the bundle. Copper ornament-total amount of copper objects in the bundle. Embroidered textiles-total amount of textiles with some special figural or geometric ornament, with the number of tapestries in parenthesis. $2 \sigma$ calibrated age AD-the absolute chronology of the bundle.

\begin{tabular}{|c|c|c|c|c|c|c|c|c|}
\hline $\begin{array}{l}\text { Burial } \\
\text { number }\end{array}$ & Gender & Age & Group & $\begin{array}{l}\text { Number of } \\
\text { textiles }\end{array}$ & Silver ornament & Copper ornament & $\begin{array}{c}\text { Embroidered } \\
\text { textiles }\end{array}$ & $\begin{array}{c}2 \sigma \text { calibrated } \\
\text { age AD }\end{array}$ \\
\hline CF 65 & $\mathrm{~F}$ & $40-45$ & $\mathrm{C}$ & 1 & - & - & - & $1209-1284$ \\
\hline $\begin{array}{l}\text { CF } 1 \\
\text { (Unidad 28) }\end{array}$ & $\mathrm{F}$ & $35-40$ & $\mathrm{~B}$ & 10 & $\begin{array}{l}\text { Necklace (alloy } \\
\text { of silver and } \\
\text { copper) }\end{array}$ & $\begin{array}{l}1 \text { necklace, } 1 \text { face } \\
\text { sheet }\end{array}$ & 一 & $1203-1284$ \\
\hline CF 72 & $\mathrm{~F}$ & $30-35$ & $\mathrm{C}$ & 0 & - & - & - & $1215-1286$ \\
\hline $\mathrm{CF} 20$ & $\mathrm{~F}$ & $30-40$ & $\mathrm{~A}$ & 12 & - & 1 face sheet & - & $1220-1290$ \\
\hline $\mathrm{CF} 12$ & $\mathrm{~F}$ & $18-20$ & B & 8 & $\begin{array}{c}\text { Ring made of } \\
\text { silver beads }\end{array}$ & - & 一 & $1221-1303$ \\
\hline CF 7 & $\mathrm{~F}$ & $30-40$ & $\mathrm{C}$ & 4 & - & - & 1 & $1229-1382$ \\
\hline CF 24 & M & $25-30$ & B & 3 & - & - & 1 tapestry & $1271-1387$ \\
\hline CF 8 & $\mathrm{~F}$ & $50-60$ & A & 15 & $\begin{array}{l}1 \text { sheet on the } \\
\text { top of the } \\
\text { head }\end{array}$ & $\begin{array}{l}2 \text { face sheets, } 1 \\
\text { necklace }\end{array}$ & - & $1274-1389$ \\
\hline CF A1 & M & $25-30$ & $\mathrm{C}$ & 4 & - & - & 1 & $1277-1390$ \\
\hline CF 112 & $\mathrm{~F}$ & $40-45$ & A & 18 & - & - & 2 & $1280-1391$ \\
\hline CF 53 & $\mathrm{~F}$ & $30-40$ & $\mathrm{~B}$ & 5 & - & 2 face sheets & - & $1285-1391$ \\
\hline CF 30 & $\mathrm{~F}$ & $40-50$ & A & 20 & $\begin{array}{l}2 \text { wrist bracelets, } \\
1 \text { necklace, } 2 \\
\text { tupu pins }\end{array}$ & $\begin{array}{l}2 \text { calf bracelets, } 7 \\
\text { face sheets, } 4 \\
\text { tupus }\end{array}$ & 一 & $1282-1391$ \\
\hline CF I & $\begin{array}{l}\text { Individual } \\
1 \mathrm{~F}, \\
\text { Individual } \\
2 \mathrm{~F}\end{array}$ & $\begin{array}{l}\text { Ind. 1: } \\
\text { 3-4; } \\
\text { Ind. 2: } \\
30-40\end{array}$ & A & $\begin{array}{l}6 \text { (and } 15 \text { more } \\
\text { textiles without } \\
\text { stratigraphic } \\
\text { position) }\end{array}$ & $\begin{array}{l}16 \text { cuadrangular } \\
\text { sheets, } 1 \\
\text { bracelet, } 1 \text { face } \\
\text { sheet }\end{array}$ & - & 1 & $1285-1391$ \\
\hline CF O-1 & $\mathrm{M}$ & $40-45$ & B & 11 & - & $\begin{array}{l}1 \text { bracelet, } 4 \text { face } \\
\text { sheets, } 1 \text { diadem, } \\
\text { necklace }\end{array}$ & - & $1287-1391$ \\
\hline
\end{tabular}


Table 2 (Continued)

\begin{tabular}{|c|c|c|c|c|c|c|c|c|}
\hline $\begin{array}{l}\text { Burial } \\
\text { number }\end{array}$ & Gender & Age & Group & $\begin{array}{l}\text { Number of } \\
\text { textiles }\end{array}$ & Silver ornament & Copper ornament & $\begin{array}{c}\text { Embroidered } \\
\text { textiles }\end{array}$ & $\begin{array}{c}2 \sigma \text { calibrated } \\
\text { age } \mathrm{AD}\end{array}$ \\
\hline CF 23 & $\mathrm{~F}$ & $20-25$ & B & 2 & - & $\begin{array}{l}1 \text { bracelet, } 2 \text { face } \\
\text { sheets }\end{array}$ & - & $1298-1397$ \\
\hline $\begin{array}{l}\text { CF } 46 \\
\text { Individual } 2\end{array}$ & M & $40-45$ & B & 8 & - & 2 face sheets & - & $1300-1404$ \\
\hline CF 36 & $\mathrm{~F}$ & $20-25$ & A & 10 & - & 2 face sheets & - & $1302-1409$ \\
\hline CF 31 & M & $30-40$ & A & 10 & 1 necklace & Semilunar headdress & 3 (1 tapestry) & $1301-1410$ \\
\hline $\mathrm{CF} \mathrm{W}$ & M & $50-60$ & B & 6 & - & - & - & $1320-1438$ \\
\hline CF 43 & M & $40-50$ & A & 4 & - & $\begin{array}{l}\text { Headdress } \\
\text { (2 semilunar } \\
\text { sheets), } \\
1 \text { tweezers }\end{array}$ & - & $\begin{array}{c}1389-1440 \\
\text { (probability: } \\
87.9 \% \text { ) }\end{array}$ \\
\hline $\begin{array}{l}\text { CF } 46 \\
\text { Individual } 1\end{array}$ & $\mathrm{~F}$ & $25-30$ & B & 4 & - & 2 face sheets & - & $1391-1447$ \\
\hline $\mathrm{CF} 47$ & M & $30-35$ & A & 11 & $\begin{array}{l}4 \text { circular plates } \\
\text { sewn to one of } \\
\text { the textiles }\end{array}$ & $\begin{array}{l}\text { Headdress } \\
\text { (1 semilunar } \\
\text { sheet), face } \\
\text { ornament ( } 3 \\
\text { decorated sheets) }\end{array}$ & 2 tapestries & $1408-1459$ \\
\hline $\begin{array}{l}\text { CF } 1 \\
\text { (Unidad 30) }\end{array}$ & M & $40-50$ & B & 4 & - & & 1 & $1411-1479$ \\
\hline
\end{tabular}

